\title{
Cellulomonas cartae sp. nov.
}

\author{
ERKO STACKEBRANDT' ${ }^{\prime}$ AND OTTO KANDLER ${ }^{2}$ \\ Deutsche Sammlung von Mikroorganismen der Gesellschaft für Strahlen- und Umweltforschung mbH, \\ Teilsammlung München, ${ }^{1}$ and Botanisches Institut der Universität München, ${ }^{2}$ D.8000 Munich 19, Federal \\ Republic of Germany
}

A cellulolytic, gram-positive organism with a high (76.6 mol\%) guanine plus cytosine content in its deoxyribonucleic acid is described as a new species, Cellulomonas cartae, because the original description and naming of this organism, as C. cartalyticum (sic), were in a patent and hence were neither effectively nor validly published. The taxonomic position of this organism as a member of the genus Cellulomonas is confirmed on the basis of biochemical and genetic characteristics. It is further shown that the new species differs from all other species of Cellulomonas described to date. The type strain of $C$. cartae is DSM 20106 (= ATCC 21681).

Carta previously described a cellulolytic organism in a patent (G. R. Carta, U.S. Patent no. $3,778,349,1973)$ describing the production of single-cell protein material. He named the organism Cellulomonas cartalyticum (sic), and a culture was deposited in the American Type Culture Collection (ATCC) under the number 21681. According to Rule 25b of the International Code of Nomenclature of Bacteria (3), however, the inclusion of a new species in a patent does not constitute effective, hence valid, publication. In addition, the organism was originally poorly described, and many characteristics necessary for the proper classification of this organism were not reported in the patent. The results of comprehensive biochemical and physiological studies (7) have shown this organism to share genus-specific characteristics with members of Cellulomonas on the one hand and to differ in many characteristics from all well-described members of this genus on the other hand. These results justify the description of this organism as a new species of Cellulomonas. The specific epithet proposed by Carta cannot be retained. Because Carta did not give the etymology of the proposed name, it is not clear whether it was formed by a combination of the Greek lyticus meaning dissolving and the author's name or the Latin noun charta, meaning paper. In the first case, the epithet cartalyticum (sic) would be meaningless; in the second case, it would mean paper-dissolving, a property common to all species of the genus. Thus, retention of this epithet would ignore recommendation $12 \mathrm{C}$ of the International Code of Nomenclature of Bacteria (3).

\section{MATERIALS AND METHODS}

Bacterial strain. DSM 20106 ( $\leftarrow$ ATCC $21681 \leftarrow$ G. R. Carta), from soil, was the only strain studied.
Growth conditions. Cultures were maintained on peptone-yeast extract-glucose (PYG) agar slants (peptone, $1 \%$; yeast extract, $0.5 \%$; glucose, $0.5 \%$ Difco agar, $1 \%)$ stored at $4^{\circ} \mathrm{C}$. Physiological tests were carried out aerobically at $30^{\circ} \mathrm{C}$ in PYG prepared without the agar. The tests for the utilization of carbon compounds, ammonium production from peptone, and nitrate reduction followed methods described elsewhere (7).

Methods. Colony morphology was observed on PYG incubated at $30^{\circ} \mathrm{C}$ for 14 days. After fixing the cells from a growing culture with osmium tetraoxide (4), treating them with uranyl acetate, and embedding them according to Spurr (5) we prepared thin sections with a LKB-Ultratome III using a glass knife. The sections were viewed with a Siemens Elmiskop Ia electron microscope.

The production of acetic acid and L-lactic acid from glucose was determined with acetate kinase (2) and L-lactate dehydrogenase (1), respectively. The enzymes were purchased from Boehringer, Mannheim. Glucose fermentation was carried out with resting cells in Warburg vessels. $\mathrm{CO}_{2}$ production was determined manometrically (8). Cellulolytic activity was tested aerobically with $0.5 \mathrm{~g}$ of Whatman no. 1 filter paper strips $(1$ by $0.5 \mathrm{~cm})$ in $30 \mathrm{ml}$ of medium $(0.5 \%$ peptone and $0.3 \%$ yeast extract, $\mathrm{pH} 7.2$ ) over a period of 10 days. The methods for the determination of the guanine plus cytosine content of the deoxyribonucleic acid (DNA) and the amino acid and sugar composition of the cell'wall are described elsewhere (6). The procedures for DNA-DNA hybridization have also been described previously (7).

\section{RESULTS AND DISCUSSION}

Cellulomonas cartae sp. nov. (car. ta'. M.L. gen. n. cartae of Carta; named for G. R. Carta, the first to isolate this organism).

Gram-positive, nonmotile rods, 0.4 by 0.6 to $1.7 \mu \mathrm{m}$ (Carta, U.S. Patent no. 3,778,349, 1973). Cells in the logarithmic growth phase are irregular, curved, and club-shaped or are arranged in $\mathrm{V}$ formation (for microphotograph, see reference 7). Approximately 4 days after exhaustion 


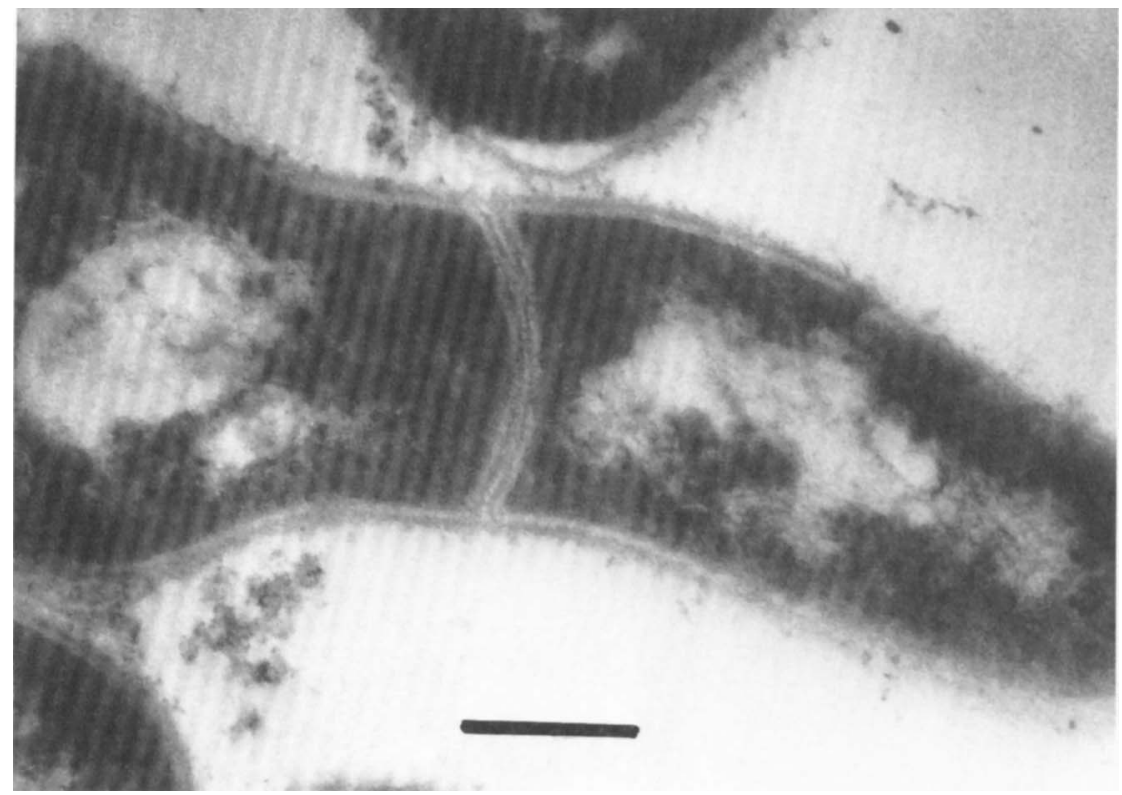

FIG. 1. Electron micrograph of an ultra-thin section of Cellulomonas cartae. Bar, $200 \mathrm{~nm}$.

of the medium, the rods transform into shorter rods or even coccoid cells. On PYG agar, colonies are about 2 to $5 \mathrm{~mm}$ in diameter, circular, convex, white, and glistening. Cells in the logarithmic phase of growth are easily decolorized with $96 \%$ ethanol when treated for longer than $9 \mathrm{~s}$ and therefore appear gram negative. However, Escherichia coli cells stain gram negative even after ethanol treatment for as short as $3 \mathrm{~s}$. Therefore, in comparison with $E$. coli, $C$. cartae is definitely gram positive. This observation was confirmed by an electron micrograph (Fig. 1) of an ultra-thin section of C. cartae, in which the typical cell wall profile of a gram-positive organism is evident.

The following are utilized as sole carbon sources: glucose, mannose, maltose, sucrose, Dxylose, L-arabinose, lactose, gluconate, mannitol, ribose, L-lactate, acetate, pyruvate, glycerol, and cellobiose. Raffinose, DL-malate, and D-lactate are not used as sole carbon sources.

Acid is produced from glucose, mannose, sucrose, $D$-xylose, L-arabinose, ribose, gluconate, glycerol, lactose, pyruvate, and cellobiose.

Acetic acid is the main acidic intermediary product of aerobic glucose dissimilation. Maximum acetic acid production $(6.5 \mu \mathrm{mol}$ of acid. per $\mathrm{ml}$ of PYG medium) is reached in 48 to $72 \mathrm{~h}$. The $\mathrm{pH}$ of the medium is 4.8. L-Lactic acid is produced in much smaller quantities $(1 \mu \mathrm{mol} / \mathrm{ml}$ of medium). After exhaustion of glucose, the acids are oxidized, resulting in an increase of the $\mathrm{pH}$ of the medium ( $\mathrm{pH} \mathrm{8.8)} \mathrm{after} 8$ days. Resting cells ferment glucose anaerobically to $\mathrm{CO}_{2}$, acetic acid, and L-lactic acid. Cellulose strips are attacked from the edges in liquid medium within the first $48 \mathrm{~h}$. No colonies are visible on the strips. After $48 \mathrm{~h}$, the paper is totally converted to a pulpy mass. The $\mathrm{pH}$ after 4 days is 5.5.

Starch is hydrolyzed and gelatin is slowly liquefied (in accord with Carta's results [Carta, U.S. Patent no. $3,778,349,1973])$.

Catalase is produced (Carta, U.S. Patent no. $3,778,349,1973$ ).

Nitrite is produced from nitrate (in accord with Carta's results [Carta, U.S. Patent no. $3,778,349,1973])$.

Acetylmethylcarbinol is not produced (Carta, U.S. Patent no. $3,778,349,1973$ ).

Urease and lysine decarboxylase are not produced (Carta, U.S. Patent no. 3,778,349, 1973).

Aerobic to facultatively anaerobic.

DNA-base composition: $76.6 \mathrm{~mol} \%$ guanine plus cytosine (6).

Cell wall composition, amino acids: DL-alanine, D-glutamic acid, L-lysine, D-serine, and Daspartic acid; peptidoglycan type: Lys-D-Ser-DAsp (6); sugars: galactose, fucose, and rhamnose (6). The cell walls do not contain teichoic acid or teichuronic acid (Fiedler, personal communication).

DNA-DNA hybridization experiments revealed a moderate relationship to other strains of Cellulomonas (12 to 20\%); almost no genetic relationship was found between $C$. cartae and strains of Arthrobacter (7).

The type strain is DSM 20106 (= ATCC 21681). 
A comparison of the characteristics of C. cartae with those of the other species of Cellulomonas is published elsewhere (7).

\section{ACKNOWLEDGMENT}

The assistance of $\mathrm{H}$. Merxmüller in determining the correct Latin form of the specific epithet cartae is greatly appreciated.

\section{REPRINT REQUESTS}

Address reprint requests to: Professor Dr. Otto Kandler, Botanisches Institut der Universität München, Menzinger Strasse 67, D-8000 Munich 19, Federal Republic of Germany.

\section{LITERATURE CITED}

1. Hohorst, H. J. 1970. L(+)-Lactat-Bestimmung mit Lactatdehydrogenase und NAD, p. 1425-1429. In H. U. Bergmeyer (ed.), Methoden der enzymatischen analyse, Bd. 2, Verlag Chemie, Weinheim

2. Holz, G., and H. V. Bergmeyer. 1970. Acetat Bestimmung mit Acetatkinase und Hydroxylamin, p. 14861490. In H. U. Bergmeyer (ed.), Methoden der enzymatischen analyse, Bd. 2, Verlag Chemie, Weinheim.

3. Lapage, S. P., P. H. A. Sneath, E. F. Lessel, V. B. D.
Skerman, H. P. R. Seeliger, and W. A. Clark. 1975. International code of nomenclature of bacteria, 1976 revision. American Society for Microbiology, Washington, D.C.

4. Ryter, A., E. Kellenberger, A. Birch-Andersen, and O. Maaløe. 1958. Etude au microscope électronique de plasmas contenant de l'acide désoxyribonucléique. I. Les nucléoides des bactéries en croissarice active. Z. Naturforsch. 13b:597-605.

5. Spurr, A. R. 1969. A low-viscosity epoxy resin embedding medium for electron microscopy. J. Ultrastruct. Res. 26:31-43.

6. Stackebrandt, E., F. Fiedler, and O. Kandler. 1978. Peptidoglycan type and cell wall polysaccharide composition of Cellulomonas cartalyticum and some coryneform organisms. Arch. Microbiol. 117:115-118.

7. Stackebrandt, E., and O. Kandler. 1979. Taxonomy of the genus Cellulomonas, based on phenotypic characters and deoxyribonucleic acid-deoxyribonucleic acid homology, and proposal of seven neotype strains. Int. J. Syst. Bacteriol. 29:273-282.

8. Stackebrandt, E., and O. Kandler. 1980. Fermentation pathway and redistribution of ${ }^{14} \mathrm{C}$ in specifically labelled glucose in cellulomonas. Zentralbl. Bakteriol. Parasitenkd. Infektionskr. Hyg. Abt. 1 Orig. Reihe C 1:40-50. 